\title{
Educação Popular, Saúde, institucionalização: temas para debate
}

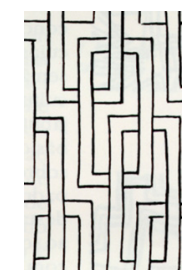

\author{
People Education, healthcare, institutionalization: themes for debate
}

José Ivo dos Santos Pedrosa ${ }^{1}$

O texto resgata a historicidade da constituição da Educação Popular em Saúde na perspectiva de quem é protagonista dessa história. Isso toca profundamente aqueles que, por alguma razão (sensibilidade, paixão, ideologia, racionalidade, opção política) se aproximam das classes populares e com elas constróem vínculos afetivos e político-ideológicos. Vínculos que promovem a vivência coletiva em torno de movimentos que levam a projetos de emancipação, libertação, autonomia, solidariedade, justiça e eqüidade. Esse agir representa, ao mesmo tempo, estratégia, metodologia, jeito de ser, visão de mundo, expressando-se por meio de um conjunto de práticas técnicas, políticas, ideológicas, culturais e psicanalíticas. As ações de Educação Popular em Saúde podem ser definidas desta maneira.

A amplitude do universo dessas práticas e a multirreferencialidade que permeia este emergente campo de conhecimento $e$ intervenção suscitam várias questões. Reapreender o significado de popular ao adjetivar Educação em Saúde no contexto atual mostra-se tarefa instigante.

O autor alimenta a discussão ao referir (p.125) que "com o processo de redemocratização da sociedade brasileira, houve espaço para que a participação popular pudesse ocorrer nas grandes instituições”. Ao atingir a dimensão institucional, a participação popular, enquanto resultado da ação educativa, suscita algumas indagações:

- Existiriam novos sujeitos envolvidos em práticas de Educação Popular em Saúde ao passarmos do "modelo dos anos setenta" - um técnico inserindo-se em uma pequena comunidade periférica, identificando lideranças e problemas mobilizadores, criando espaços de debates, apoiando as lutas emergentes e trazendo subsídios teóricos para alargar as discussões locais - para o modelo da participação institucional?

- Quais as características desses sujeitos e seus projetos de intervenção na realidade social? É o adjetivo "popular" que se apresenta como dispositivo para sensibilizar e produzir novas subjetividades nos saberes e práticas dos profissionais de saúde?

${ }^{1}$ Centro de Ciências da Saúde, Universidade Federal do Piauí. <jivo@ufpi.br> 
- Quais os espaços em que as práticas de Educação Popular em Saúde são desenvolvidas e se reproduzem? Nos indivíduos, grupos, organizações e instituições?

Estas perguntas necessitam de maiores reflexões para tornarem-se problematizadoras. Em primeiro lugar, é preciso reconhecer que "o popular" da Educação em Saúde contém explícito ou implícito um projeto de libertação, de autonomia e de co-gestão, cujas ações voltam-se para a construção de sujeitos sociais - pessoa em busca de autonomia, disposta a correr riscos, a abrir-se ao novo, ao desconhecido, e na perspectiva de ser alguém que vive numa sociedade determinada, capaz de perceber seu papel pessoal/ profissional/social diante dos desafios colocados a cada momento (L'Abbate, 1994).

Ao trabalhar com sujeitos sociais a Educação Popular em Saúde tem como missão contribuir para a construção de cenários nos quais esses sujeitos possam se movimentar em busca do futuro desejado. No Brasil, as mudanças estruturais não foram suficientes para transformações organizacionais mais profundas; entretanto, novos atores e novos elementos foram incorporados aos cenários, cada qual trazendo temáticas, apresentando experiências e desejos.

Em segundo lugar, deve-se considerar que a participação popular no âmbito das instituições requer que o ator representante dos interesses das classes populares, além de sujeito social, apresente características necessárias para participar das arenas decisórias, manejando os recursos de poder que circulam no campo da Saúde, acumulando suficiente poder político para viabilizar o projeto de intervenção na Educação Popular, instrumentalizando profissionais de saúde, intelectuais e lideranças populares, para além da sensibilização.

O habitus de profissionais de saúde engajados nos movimentos sociais $e$ comprometidos com a comunidade, e valores éticos imanentes ao projeto político-pedagógico da educação popular em saúde revelam o compromisso não somente com a mudança de atitudes e comportamentos, mas com a construção do sujeito/cidadão.

Finalmente, ao referir-se à população que utiliza os serviços do SUS, o "popular" evidencia o usuário participante da produção de ações de saúde em coletivos organizados (as unidades de produção) que significam espaços de um trabalho que considera tanto os interesses e desejos do agente produtor quanto necessidades sociais (Campos, 2000). Além disso, o reconhecimento do outro (usuários) possibilita a abertura das organizações prestadoras de serviços ao olhar e à participação desses usuários no processo de produção de ações de saúde, conformando momentos de excelência para a discussão $e$ recomposição de novas práticas voltadas para promoção da saúde como resultado da ação educativa e para institucionalização de novas modalidades de gestão e gerenciamento participativos.

Referências bibliográficas

L'ABBATE, S. Educação em Saúde: uma nova abordagem. Cad. Saúde Pública, v.10, n.4, p.481-490, 1994.

CAMPOS, G.W. Um método para análise e co-gestão de coletivos. São Paulo: Hucitec, 2000. 